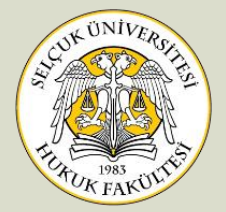

\title{
ELEKTRONIK ÜRÜNLER İÇINN YAPILAN İNTERNET SATIŞLARINDA CAYMA HAKKININ KULLANILMASI VE MUTAT KULLANIM KAVRAMI
}

Dr. Öğr. Üyesi Ayşen ÇíLENTİ KONURALP*

Öz

Mesafeli satım sözleşmelerinde tüketiciye tanınan cayma hakkı sayesinde, tüketici ürünü görme ve inceleme, sonrasında ise kural olarak on dört gün içerisinde sözleşmeden cayarak satış bedelinin iadesini talep etme imkânını elde eder. Cayma hakkına başvurulmasından evvel sözleşme konusu malın tüketici tarafından kullanılıp kullanılamayacağı ve böyle bir kullanımın cayma hakkı bakımından hukuki sonucunun ne olacağı ise tartışmalıdır. Bunun yanında, mevzuatta cayma hakkının satım konusu malın niteliği gereği kullanılamayacağı bazı istisnai durumlar düzenlenmiştir. Tüm bu hususlar, bilhassa internet ortamında yapılan elektronik ürün satışlarında cayma hakkının kullanılması bakımından bazı nitelikli durumlar ortaya çıkmasına neden olur. Bu çalışma, anılan hukuki sorunları Avrupa Birliği'nin 2011/83/EU sayılı Tüketici Hakları Direktifi, 6502 sayılı Tüketicinin Korunması Hakkında Kanun ve Mesafeli Sözleşmeler Yönetmeliği kapsamında incelemeyi amaçlamaktadır.

\section{Anahtar Kelimeler}

Tüketicinin Korunması • Cayma Hakkı • Mesafeli Satım Sözleşmesi • Elektronik Sözleşme • Mutat Kullanım

* Dr. Öğr. Üyesi, İstanbul Aydın Üniversitesi Hukuk Fakültesi, Medenî Hukuk ABD, İstanbul, Türkiye | Asst. Prof., İstanbul Aydın University Faculty of Law, Department of Civil Law, İstanbul, Turkey.

囚aysencilentikonuralp@aydin.edu.tr • ORCID 0000-0002-5626-6970

Atıf Şekli | Cite As: KONURALP ÇİLENTİ Ayşen, “Elektronik Ürünler İçin Yapılan İnternet Satışlarında Cayma Hakkının Kullanılması ve Mutat Kullanım Kavrami", SÜHFD., C. 29, S. 4, 2021, s. 2729-2759.

İntihal | Plagiarism: Bu makale intihal programında taranmış ve en az iki hakem incelemesinden geçmiştir. | This article has been scanned via a plagiarism software and reviewed by at least two referees. 


\title{
RIGHT OF WITHDRAWAL ON INTERNET SALES FOR ELECTRONIC PRODUCTS AND THE USE OF PRODUCT
}

\begin{abstract}
By means of the right of withdrawal granted to the consumers in distance sales contracts, consumers can see and examine the product, and then, as a rule, to withdraw from the contract within fourteen days and demand the return of the sales price. It is legally controversial whether the goods subject to the contract can be used by the consumer before the exercise of the right of withdrawal and what the legal consequences of such use will be in terms of the right of withdrawal. Besides this, exceptional conditions have been regulated in the legislation in which the right of withdrawal cannot be exercised due to the nature of the goods. All these lead to further controversies especially on the sale of electronic products via internet. This study aims to examine the mentioned legal issues within the scope of the EU Directive on Consumer Rights No. 2011/83/EU, the Consumer Protection Law No. 6502 and the Regulation on Distance Contracts.
\end{abstract}

\section{Key Words}

Consumer Protection • Right of Withdrawal • Distance Sales Contract • Electronic Contract • Ordinary Use

\section{Gİiș}

Mesafeli sözleşmelerde tüketiciye tanınan cayma hakk1 ${ }^{1}$, tüketicinin korunmasının en etkin yollarından biri olarak kabul edilmektedir. Tüketici bu hak sayesinde, mesafeli satımlarda ürünü görme ve inceleme, sonrasında ise kural olarak on dört gün içerisinde sözleşmeden cayarak satış bedelinin iadesini talep etme imkânını elde eder. Böylece tüketici herhangi bir bedel ödemeksizin ve gerekçe sunmaksızın mesafeli satım sözleşmesiyle bağlı olmaktan kurtulur. Mesafeli sözleşmelerde cayma hakkının kullanılması, öğretide pek çok yönüyle teorik tartışmalara neden olmuştur. Bu tartışmalardan biri de cayma hakkına başvurulmasından evvel sözleşme konusu malın tüketici tarafından kullanılmasının, cayma hakkı bakımından sonucunun ne olacağıdır. Tüketicinin Korunması Hakkında Kanun (TKHK) md. 48/4 ve Mesafeli Sözleşmeler

1 Öğretide, cayma hakkı terimi bakımından bir tartışma söz konusudur. Bir görüş, cayma hakkı ifadesinin isabetli olmadığını ve geri alma hakkı ifadesinin kullanılması gerektiğini ifade etmektedir. Bu tartışmalar için Bkz. BAYSAL, Başak, "Cayma Hakkının Sözleşme Hukukundaki Yeri", İstanbul Üniversitesi Hukuk Fakültesi Mecmuası, Cilt LXXV, Sayı 1, Y11 2017, s. 274, dn. 2. 
Yönetmeliği (Yönetmelik) md. 13/2 gereği, tüketici sadece malın “mutat kullanımı" dışında kalan fiillerin yarattığı değişim ve bozulmalardan sorumludur. Avrupa Birliği Tüketici Hakları Direktifi (Direktif) md. $14 / 2^{2}$ ye göre de tüketici yalnızca malın yapısını, niteliğini ve kullanımını kavramak için gerekli olan fiiller dışında kalan kullanımdan kaynaklanan değer azalmalarından sorumlu olur. Öğretide de malın tüketici tarafından mutat kullanımı aşan şekilde kullanılmasının cayma hakkına başvurulmasına engel teşkil etmediği, fakat tüketicinin değer azalmasindan sorumlu tutulacağı kabul edilmektedir ${ }^{3}$. Bu doğrultuda, mutat kullanım kavramının anlamının tespit edilmesi gerekir. Bunun yanında Yönetmelik md. 15 cayma hakkının kullanılamayacağı bazı istisnai halleri düzenlemiştir. Uygulamadaki yaygınlığı dolayısıyla, elektronik ürün satışlarında mutat kullanım kavramının nasıl değerlendirileceği, mutat kullanımın aşılmış olmasının cayma hakkına başvurulmasını engelleyip engellemeyeceği, elektronik ürünlerin cayma hakkının kullanılamayacağı istisnai hallerden sayılıp sayılmadığ satış yapan satıcıların elektronik ürünlerde cayma hakkının kullanımını kısıtlayan beyanlarının hangi ölçüde hukuki sonuç doğuracağı, tartışmaya değer güncel hukuki sorunlar doğurur. Avrupa Birliği mevzuatı ve Avrupa Birliği Adalet Divanı kararları Türk Hukuku açısından bağlayıcı olmasa da TKHK ve Yönetmelik, büyük ölçüde Avrupa Birliği tüketici hukukunun ve Direktif'in etkisi ile oluşturulan düzenlemelerdir $^{4}$. Bu nedenle Direktif kapsamında yapılan hukuki tartışmalar ve yo-

"The consumer shall only be liable for any diminished value of the goods resulting from the handling of the goods other than what is necessary to establish the nature, characteristics and functioning of the goods."

3 Bu görüşler için bkz. Aşa. III, B.

46502 sayılı Tüketicinin Korunması Hakkında Kanun, AB tüketici mevzuatının iç hukuka aktarılması amacıyla düzenlemeler öngörmüştür. Bkz. AYDOĞDU, Murat, “6502 Sayılı Tüketicinin Korunması Hakkında Kanun'un Getirdiği Yeniliklere Genel Bakış, Sözleşmeye Aykırılık, Ayıplı İfa Kavramlarına Getirdiği Farklı Yaklaşım ve Bu Konudaki Önerilerimiz", Dokuz Eylül Üniversitesi Hukuk Fakültesi Dergisi, Cilt 15, Sayı 2, Yı1 2013, s. 4. Aynı yönde bkz. DÖNMEZ, Zeynep, “2011/83/EU Sayılı Tüketici Hakları Direktifi ve Bu Direktifin Mesafeli Sözleşmeler Alanında Türk Hukuku'na Yansımaları", İnönü Üniversitesi Hukuk Fakültesi Dergisi, Cilt 7, Sayı 1, Yıl 2016, s. 351. Keza, TKHK'nın amacını açıklayan 1. maddesi, Avrupa Birliği'nde kabul edilen tüketicinin beş temel hakkını içermektedir. Bkz. SİRMEN, A. Lâle, "Tüketici Hukukunun Amacı ve Özellikleri”, Yaşar Üniversitesi E-Dergisi, Say1 8 (Özel Say1), Y1l 2013, s. 2467. 
rumlar, Türk Hukuku bakımından yol göstericidir. Bu çalışma, anılan hukuki sorunları TKHK, Direktif ve Yönetmelik kapsamında incelemeyi amaçlamaktadır.

Son olarak şunu özellikle ifade etmek isteriz: Gerek mesafeli sözleşme kavramı gerekse cayma hakkı, öğretide pek çok yönü ile tek bir monografinin kapsamını aşabilecek teorik tartışmalara konu olmuştur. $\mathrm{Bu}$ çalışma, mesafeli sözleşme ve cayma hakkı kavramlarını, yukarıda özellikle anılan sorunlar kapsamında incelemeyi amaçladığından, bu kavramlara yönelik her türden teorik tartışma ayrıca incelenmemektedir.

\section{MESAFELİ SATIM SÖZLEŞMELERINDE CAYMA HAKKI}

\section{A. Mesafeli Satım Sözleşmeleri Kapsamında İnternet Satışları}

Sözleşme, en başat ifadesi ile bir irade mutabakatıdır5. Bu mutabakat çoğu zaman, öncesinde tarafların sözleşme kurma iradesini oluşturmak için müzakere ettikleri bir aşama gerektirir. Müzakere ve kurulma aşamaları alıcı ile satıcının karşı karşıya gelmeden, mektup, telefon, faks, e-posta, akıllı uygulamalar gibi her türden yazılı, görsel veya elektronik iletişim aracı ile gerçekleştirilen sözleşmeler ise mesafeli sözleşme olarak adlandırılmaktadır ${ }^{6}$. TKHK md. 48/1 ve Yönetmelik md. 4/e de benzer

5 KOCAYUSUFPAŞAOĞLU, Necip, Borçlar Hukuku Genel Bölüm, Birinci Cilt, Filiz Kitabevi, 4. Bası, İstanbul 2008, s. 95 vd.

6 ÇABRI, Sezer, Tüketicinin Korunması Hakkında Kanun Şerhi, 2. Baskı, Adalet Yayınevi, Ankara 2021, s. 870; AYDOĞDU, Murat/KAHVECİ, Nalan, Tüketici Hukuku, Adalet Yayınevi, Ankara 2021, s. 406; ÖZLÜK, Betül, “Akıllı Mesafeli Sözleşmelerde Bilgilendirme Yükümlülüğ̈̈", Bilişim Hukuku Dergisi, Sayı 1, Yıl 2020, s. 86; AKKURT, Sinan Sami, “Elektronik Ortamda Hizmet Sunumu ve Buna İlişkin Sözleşmelerin Hukuki Özellikleri", Ankara Üniversitesi Hukuk Fakültesi Dergisi, Cilt 60, Sayı 1, Yil 2011, s. 35; MODUL 2, s. 7; STEENNOT, Reinhard, "The Right Of Withdrawal Under The Consumer Rights Directive As A Tool To Protect Consumers Concluding A Distance Contract", Computer Law \& Security Review, Say1 29, Y1l 2013, s. 107; AVCI BRAUN, Cihan, "Tüketicinin Korunması Hakkında Kanun Kapsamında Mesafeli Sözleşmeler", Yeditepe Üniversitesi Hukuk Fakültesi Dergisi Tüketici Hukuku Sempozyumu Özel Sayı, Cilt XII, Sayı 2, Yıl 2015, s. 29; UYUMAZ, Alper, "Elektronik Sözleşmelerin Web Siteleri Aracılığıyla Kurulması ve Bu Sözleşmelerin İfası", Dokuz Eylül Üniversitesi Hukuk Fakültesi Dergisi, Cilt 9, Özel Sayı, Yıl 2007, s. 912 vd.; BOZBEL, Savaş / ATALI, Murat, “Mesafeli Sözleşmelerde Cayma Hakkının Kullanılması ve Ortaya Çıkan Hukuki Sorunlar", Atatürk Üniversitesi Erzincan Hukuk Fakültesi Dergisi, Cilt IX, Say1 1-2, Y1l 2005, s. 451; BÜTÜN YILMAZ, Derya G., "Mesafeli Sözleşmelerin Kapsamı”, Ankara Üniversitesi Hukuk Fakültesi Dergisi, Cilt 69, Sayı 2, Y1l 2020, s. 330 vd.; BOZBEL, Savaş, “Türk Huku- 
bir tanımı içermektedir. Buna göre: "Mesafeli sözleşme, satıcı veya să̆layıcı ile tüketicinin eş zamanl fiziksel varlığı olmaksızın, mal veya hizmetlerin uzaktan pazarlanmasına yönelik olarak oluşturulmuş bir sistem çerçevesinde, taraflar arasında sözleşmenin kurulduğu ana kadar ve kurulduğu an da dâhil olmak üzere uzaktan iletişim araçlarının kullanılması suretiyle kurulan sözleşmelerdir." Ayrıca, hükmün lafzından da anlaşıldığı üzere, mesafeli sözleşmelerde sadece müzakere veya kuruluş aşamalarından birinin "uzaktan" gerçekleştirilmesi yeterli sayılmaz. Bu iki aşamadan biri satıcının iş yerinde gerçekleştiyse, sözleşme "mesafeli" yapılmış sayılmamaktadır7.

Bir sözleşmenin mesafeli sözleşme sayılması için gerekli olan bir diğer unsur ise, satıcının mesafeli sözleşme yapma amacıyla bir sistem kurmuş olmasıdır. TKHK md. 48/1 hükmü lafzında bu husus açıkça ifade edilmektedir. Dolayısıyla satıcının münferit olarak ve bir sistem kurmadan yapmış olduğu sözleşmeler, iletişim araçları ile uzaktan kurulmuş olsalar bile TKHK anlamında mesafeli sözleşme kavramına girmeyeceğinden, tüketicinin de mesafeli sözleşmelere özgü koruma imkanlarından -özellikle cayma hakkından- faydalanması söz konusu olmaz ${ }^{8}$. Örneğin, sosyal medya profiline ilan koyarak ve bu mecradan iletişim kurarak eski bilgisayarını satan kişinin, bu satış için bir sistem kurduğu söylenemez. Bu durumda, mesafeli sözleşmenin varlığı ve tüketicinin bu sözleşme kapsamında korunması söz konusu olamaz.

Mesafeli sözleşme, her türden özel sözleşme türünü içinde barındırabilen bir genel kavramdır. Zira bu kavram, bir sözleşme kurma biçimini ifade eder ${ }^{9}$. Dolayısıyla her türden sözleşme, aksine bir düzenle-

kunda mesafeli Sözleşmeler", Atatürk Üniversitesi Erzincan Hukuk Fakültesi Dergisi, Cilt VII, Sayı 3-4, Yıl 2003, s. 785; DEMİR, Mehmet, “Mesafeli Sözleşmelerle İlgili AB Yönergesine Göre Tüketicinin Geri Alma Hakkı", Gazi Üniversitesi Hukuk Fakültesi Dergisi, Cilt 7, Sayı 1-2, Y1l 2003, s. 66; YÜCEDAĞ GÖZTEPE, Nafiye, "Mesafeli Sözleşmelerde Tüketicinin Cayma Hakkı", Türkiye Adalet Akademisi Dergisi, Sayı 27, Yıl 2016, s. 668; AYDOĞDU, Murat, Tüketici Kılavuzu-Hukuk Rehberi, On İki Levha Yayıncılık, İstanbul 2014, s. 134.

7 ÖZLÜK, s. 87; BÜTÜN YILMAZ, s. 331; UZUN KAZMACI, Özge, “İnternet Ortaminda Kurulan Mesafeli Sözleşmelerde Tüketicinin Korunması", Marmara Üniversitesi Hukuk Fakültesi Hukuk Araştırmaları Dergisi, Prof. Dr. Cevdet Yavuz'a Armağan Özel Sayısı, Cilt 22, Sayı 3, Yı1 2016, s. 2795; AYDOĞDU, Kılavuz, s. 134.

$8 \quad$ UZUN KAZMACI, s. 2795. Bu yönde bkz. BÜTÜN YILMAZ, s. 332; BOZBEL, s. 788; YÜCEDAĞ GÖZTEPE, s. 669; AYDOĞDU, Kılavuz, s. 135.

9 ÖZLÜK, s. 88; AVCI BRAUN, s. 22. 
me yoksa, kural olarak mesafeli sözleşme biçiminde kurulabilir ${ }^{10}$. Bu nedenle, günümüzde bilhassa teknolojik gelişmelerin sonucunda kullanım alanı gittikçe yaygınlaşmaktadır ${ }^{11}$. Bu aşamada, elektronik sözleşme ve internet satışı kavramlarını ayrıca incelemek gerekir.

Elektronik ticaret ve elektronik sözleşme kavramı, elektronik iletişim araçları aracılığıyla yapılan işlemleri ifade eder ${ }^{12}$. Sözleşme yapma amacı taşıyan tarafların sözleşme yapma iradelerinin elektronik veriler yoluyla açıklandığı her türden araç, elektronik sözleşmeye aracılık teşkil edebilir $^{13}$. Bu türden işlemler, internet bağlantısı aracılığıyla kurulabildiği gibi, telefon, faks, teleks gibi geleneksel elektronik iletişim yolları ile de oluşturulabilir ${ }^{14}$. İnternet satışı ise, internet yoluyla ve internet araçlarının kullanılması ile kurulan sözleşmeyi ifade eder ${ }^{15}$. Bu bağlamda, elektronik sözleşme kavramının, internet satışı kavramında daha geniş bir anlamı olduğunu, internet yolu ile kurulan sözleşmelerin ise elektronik sözleşmelerin bir türü olduğunu ifade etmek gerekir ${ }^{16}$. İnternet satışları, ekonomik getirileri ve sağladıkları kolaylık ile günümüzde elektronik sözleşmelerin en yaygın türünü oluşturmaktadır ${ }^{17}$.

Elektronik sözleşmelerin hukuki niteliklerinden biri, mesafeli sözleşme olmalarıdır ${ }^{18}$. Elektronik sözleşmelerin bir türü olan internet satışları da mesafeli sözleşmelerden sayılmaktadır ${ }^{19}$. Tabii, internet satışının tüketici hukuku anlamında mesafeli sözleşme sayılabilmesi için, tüketici işlemlerinin diğer şartlarını da taşıması gerektiği göz ardı edilmemelidir. Zira, tüketici sıfatı taşımayan kişilerin internet aracılığıyla kurduğu söz-

10 AVCI BRAUN, s. 22. Mesafeli Sözleşmeler Yönetmeliği md. 2/2 bazı sözleşme türlerini kapsam dışında bırakmıştır. Kapsam dışı unsurlar bu çalışmada ayrıca incelenmeyecektir.

11 AVCI BRAUN, s. 18.

12 AKKURT, s. 22; UYUMAZ, s. 908.

13 AKKURT, s. 25.

$14 \quad$ AKKURT, s. 22, 26.

15 UZUN KAZMACI, s. 2792; ÖZLÜK, s. 94; AKKURT, s. 22.

16 UZUN KAZMACI, s. 2793; AKKURT, s. 35; bu yönde UYUMAZ, s. 908.

17 UYUMAZ, s. 910; UZUN KAZMACI, s. 2792.

18 AKKURT, s. 30; MODUL 2, s. 8; UYUMAZ, s. 916.

19 ÖZLÜK, s. 94. 
leşmeler de elektronik sözleşme kavramının kapsamına dahil olmakta$\mathrm{d}_{1} \mathrm{r}^{20}$.

İnternet yoluyla kurulan elektronik sözleşmeler, uygulamada çoğunlukla etkileşimli internet siteleri aracılığıyla kurulmaktadır. Etkileşimli internet sitesi, bu ortamda satış yapan satıcının doğrudan pazarlama yapmasına imkân tanınan, satıcının sözleşmenin esaslı unsurlarını yayınladığı internet sitesi üzerindeki beyanının icap niteliğinde kabul edildiği, böylece alıcının kabul beyanı ile sözleşmenin kurulabildiği elektronik ortamdır ${ }^{21}$. Günümüzde bu türden internet siteleri, gerek bireylerin çok büyük çoğunluğunun kullandığı akıllı telefon uygulamalarıyla yapılan işlemlerde ${ }^{22}$ gerekse ekonomik getirileriyle tercih nedeni olan internet satışlarında ${ }^{23}$ kullanılmakta ve bu işlemler mesafeli sözleşmelerin en önemli örneklerini oluşturmaktadır. İnternet satışlarının bu denli yaygınlaşması ve bu yöndeki düzenleme ihtiyacı, Türk tüketici mevzuatında yapılan değişikliklerin de en önemli nedenlerinden biri$\operatorname{dir}^{24}$.

\section{B. İnternet Satışlarında Cayma Hakkının Kullanılması}

\section{a. Genel Olarak}

Tüketicinin en üst seviyede korunması, Avrupa Birliği hukuk politikasının en öncelikli amaçlarından biri olarak görülmektedir ${ }^{25}$. Cayma

20 Benzer tespit için bkz. ÖZLÜK, s. 94; UYUMAZ, s. 916; BÜTÜN YILMAZ, s. 329; BOZBEL, s. 786.

21 AKKURT, s. 40.

22 Akıllı uygulamalar ile yapılan işlemlerin mesafeli sözleşme niteliği için bkz. ÖZLÜK, s. 88.

23 AVCI BRAUN, s. 19.

24 Hem 4077 sayılı kanunda yapılan değişikliklerde, hem de 6502 sayılı kanunun hazırlanmasında bu saik için bkz. AYDOĞDU, s. 4. Mesafeli satım sözleşmelerinde tüketicinin korunmasına ilişkin hükümler henüz kanuni düzenlemelerde yer almazken, agresif satış yöntemleri nedeniyle kapıdan satışlarda geri alma hakkı düzenlenmişti. Bkz. KURT, Leyla Müjde, “TKHK Açısından Kapıdan Sözleşmelerde Tüketiciyi Koruyan Geri Alma Hakkı”, Ankara Barosu Dergisi, Sayı 2, Y11 2011, s. 45 vd.

25 SÁNCHEZ ABRIL, Patricia / OLIVA BLÁZQUEZ, Francisco / MARTÍNEZ EVORA, Joan, "The Right of Withdrawal in Consumer Contracts: a comparative analysis of American and European Law", InDret, Say1 3, Y11 2018, s. 30; GEZDER, Ümit, "The Right of Withdrawal in Distance Contracts", Yaşar Üniversitesi E-Dergisi, Say1 8, Y1l 2013, s. 1185. 
hakkı sayesinde tüketiciye tek taraflı olarak ve hiçbir gerekçe sunmaksızın sözleşme ile bağlı olmaktan kurtulma "kudreti" tanınmış olması da bu koruma amacının bir yansımasıdır ${ }^{26}$. Gerçi, tüketiciye tanınan cayma hakkı öğretide pacta sunt servanda ilkesine aykırılık teşkil edip etmediği bakımından tartışılmış ve öğretinin bir kısmınca eleştirilmiş olsa da ${ }^{27}$, aşağıda da incelendiği üzere hem Avrupa Birliği hem de bunun tüketici hukuku bakımından fazlasıyla etkilediği Türk Hukukunda tüketicinin korunması bakımından geniş yer tutmaktadır.

Cayma hakkı, tüketiciye, herhangi bir gerekçe sunmaksızın ve cezai şart ödemeksizin mesafeli satım sözleşmesi ile bağlı olmaktan kurtulma imkânı veren bir haktır ${ }^{28}$. Bu esas, TKHK md. 48/4, Yönetmelik md. 11 ve Direktif md. 9 vd. düzenlenmektedir. Cayma hakkının kullanılmasından evvel sözleşme kurulmuş ve taraflar sözleşme ile bağlı duruma gelmiştir ${ }^{29}$. Sözleşme ile bağlı olması beklenen tarafın, sözleşmeden böylesine kolayca "kurtulmasına" imkân veren bu hakkın tanınması ise, bizatihi mesafeli sözleşmelerin "mesafeli" niteliğinden kaynaklanır. Mesafeli sözleşme kuran tüketici, klasik alışveriş hayatında olduğu gibi sözleşmenin karşı tarafını görmemekte, ayrıca malı muayene etme ve hakkında yeteri kadar bilgi sahibi olma imkanını elde edememektedir. Bu nedenle tüketicinin, sözleşme konusu mal hakkında yeteri kadar bilgi sahibi olmadan sözleşme yapma tehlikesi vardır ${ }^{30}$. İşte bu bilgi asi-

26 ABRIL/BLANQUEZ/EVORA, s. 31.

27 GEZDER, s. 1188; LUZAK, Joasia, “To Withdraw or Not to Withdraw? Evaluation of the Mandatory Right of Withdrawal in Consumer Distance Selling Contracts Taking into Account Its Behavioural Effects on Consumers", Journal of Consumer Policy, Centre for the Study of European Contract Law Working Paper Series No. 2013/04, s. 1. Bu yönüyle cayma hakkının sözleşme ile bağlılık prensibinin bir istisnası mi, yoksa onun tamamlayıcısı mı olduğu yönündeki tartışmalar ve cayma hakkının sözleşme ile bağlılık ilkesinin tamamlayıcısı olduğu yönündeki görüş için bkz. BAYSAL, s. 277 vd.

28 BAYSAL, s. 275; STEENNOT, s. 106; ÇABRİ, s. 64; AVCI BRAUN, s. 36; DÖNMEZ, s. 368. Dolayısıyla cayma hakkı, halihazırda kurulmuş ve bağlayııı olan bir sözleşme ilişkisinin çözülmesini sağlar. Bu yönüyle sadece bir "düşünme süresinden" (Thinking period) ayrılır. Zira düşünme süresi içerisinde sözleşmenin henüz kurulmamış, tüketicinin de henüz ifayı talep edemez durumda olduğu kabul edilir. Bkz. Gezder, s. 1191.

29 BAYSAL, s. 277; GEZDER, s. 1193.

30 BAYSAL, s. 275, dn. 5, s. 284; ÇABRİ, s. 868; BAŞ SÜZEL, Ece, “Mesafeli Sözleşmelerde Tüketicinin Sözleşmenin Kurulmasından Önce Korunması: Ön Bilgilendirme Yükümlülüğ̈̈", Galatasaray Üniversitesi Hukuk Fakültesi Dergisi, Cilt 2, Sayı 2, Yıl 
metrisi, mesafeli sözleşmelerde tüketicinin hukuki durumunun özel olarak düzenlenmesini ve tüketicinin korunmasını gerektirmiştir ${ }^{31}$. Keza, tüketicinin elektronik iletişim araçları ile kolaylıkla uzaktan sözleşme kurabiliyor olması, riskin gerçekleşme ihtimalini arttırmaktadır. Zira bu kolaylık, uygulamadaki işlem sayısını arttırır ${ }^{32}$. İnternet araçlarının pek çok özelliğini bilmeyen ve bu yönüyle zarar görmeye açık olan tüketicinin korunması gerekir ${ }^{33}$. Cayma hakkı ayrıca, tüketim çağında bireyin rasyonel olmayan tüketim davranışlarının telafisi için bir araçtır ${ }^{34}$. Üstelik tüketicinin üstlendiği riskin ve bundan kaynaklanan zararın artması, piyasa dengesini bozabilecek, sonuç olarak ise tüm piyasa aktörlerinin zarara uğramasına neden olabilecek bir husustur. Dolayısıyla, tüketiciye yönelik koruyucu düzenlemeler, dolaylı olarak tüm piyasa aktörlerini korumaktadır ${ }^{35}$. Bu nedenle cayma hakkı, tüketiciye aksi kararlaştırılamayacak biçimde tanınmıştır ${ }^{36}$. Böylece, mesafeli sözleşme yapan tüketici satıcıyı/sağlayıcıyı ve ürünü görmeden, yalnızca iletişim araçları ile uzaktan bir sözleşme ilişkisi kurduğu için, kanun koyucu tarafından özel olarak korunmuştur.

\section{b. Tüketicinin Cayma Hakkı Konusunda Bilgilendirilmesi}

Tüketicinin mesafeli satım sözleşmesinde cayma hakkı ile korunması, ancak bu hakka sahip olduğunu ve nasıl kullanacağını bilmesi ile sağlanabilir. Bu korumanın sağlanması amacıyla öncelikle TKHK md. 48 ve Yönetmelik md. 5, mesafeli sözleşmelerde tüketiciye bilgi verme yükümlülügünü özel olarak düzenlemiştir.

İlk olarak, tüketicinin mesafeli satım sözleşmelerinde cayma hakkı bakımından bilgilendirilmesi Yönetmelik'in 5/1 maddesinin g, $\breve{g}$ ve $h$

2018, s. 340; MODUL 2, s. 7; ABRIL/BLANQUEZ/EVORA, s. 32; AVCI BRAUN, s. 19; BÜTÜN YILMAZ, s. 338; UZUN KAZMACI, s. 2801; BOZBEL, s. 799; DÖNMEZ, s. 358; DEMIR, s. 66; BOZBEL/ATALI, s. 452; YÜCEDAĞ GÖZTEPE, s. 669.

31 ÇABRİ, s. 881; BAYSAL, s. 281; AYDOĞDU/KAHVECİ, s. 881; BAŞ SÜZEL, s. 341; AVCI BRAUN, s. 36; GEZDER, s. 1188; UZUN KAZMACI, s. 2801; DEMİR, s. 71; BOZBEL/ATALI, s. 452.

32 BAŞ SÜZEL, s. 341; GEZDER, s. 1189; UZUN KAZMACI, s. 2806; DÖNMEZ, s. 363.

33 UYUMAZ, s. 916.

34 BAYSAL, s. 275, 280; BOZBEL/ATALI, s. 452; YÜCEDAĞ GÖZTEPE, s. 669.

35 Bu yönde bkz. BAŞ SÜZEL, s. 342.

36 SİRMEN, s. 2468. Fakat öğretide bu husus eleştirilmektedir. Bkz. YÜCEDAĞ GÖZTEPE, s. 670 . 
bentlerinde oldukça ayrıntılı olarak düzenlenmiştir. Buna göre "cayma hakkının olduğu durumlarda, bu hakkın kullanılma şartları, süresi, usulü ve satıcının iade için öngördü̈̆̈̈ taşıyıcıya ilişkin bilgiler, cayma bildiriminin yapılacağ $ı$ açık adres, faks numarası veya elektronik posta bilgileri, 15 inci madde uyarınca cayma hakkının kullanılamadığ kından faydalanamayacă̆ına ya da hangi koşullarda cayma hakkını kaybedeceğine ilişkin bilgi" tüketiciye verilmelidir. Zira tüketici, ancak cayma hakkı konusunda bilgi sahibi ise bu hakkı gereği gibi kullanabilir ${ }^{37}$.

İnternet üzerinden kurulan sözleşmelerde ise satıcıya bu bilgilendirme konusunda ek yükümlülükler getirilmiştir ${ }^{38}$. Yönetmelik md. 6/2'ye göre satıc1/sağlayıcı, sözleşme konusu mal veya hizmetin temel nitelikleri, mal veya hizmetin tüm vergiler dahil toplam fiyatı, niteliği itibariyle önceden hesaplanamıorsa fiyatın hesaplanma usulü, varsa tüm nakliye, teslim ve benzeri ek masraflar ile bunların önceden hesaplanamaması halinde ek masrafların ödenebileceği bilgisi, cayma hakkının olduğu durumlarda, bu hakkın kullanılma şartları, süresi, usulü ve satıcının iade için öngördüğü taşıyıcıya ilişkin bilgiler ve 15 inci madde uyarınca cayma hakkının kullanılamadığı durumlarda, tüketicinin cayma hakkından faydalanamayacağına ya da hangi koşullarda cayma hakkını kaybedeceğine ilişkin bilgi hakkında tüketicinin ödeme yükümlülüğü altına girmesinden hemen önce açık bir şekilde bilgilendirmede bulunmak ve herhangi bir gönderim kısıtlamasının uygulanıp uygulanmadığını ve hangi ödeme araçlarının kabul edildiğini, en geç tüketici siparişini vermeden önce, açık ve anlaşılabilir bir şekilde belirtmek zorundadır. Direktif md. 8/2 hükmü, Yönetmelik'in md. 6/2 hükmüne kaynaklık etmiştir. Direktif gerekçesinin 39. paragrafı md. 8/2'nin amacını, tüketicinin verdiği onay ile sözleşme kurarak bir ödeme yükümlülüğü altına girdiği yönünde dikkatinin çekilmesi olarak açıklamaktadır. Böylece tüketici, internet satış sitesinde tek bir "tıklama" işlemi ile ortaya çıkan sonucu ve üstlendiği yükümlülüğü açıç̧a kavrayabilecek duruma getirilecektir ${ }^{39}$. Kanımızca, tüketicinin internet ortamında oldukça basit bir işlem ile üstleneceği bu olası yükümlülüklerden önce işlemin

37 ROTT, Peter, "Harmonising Different Rights of Withdrawal: Can German Law Serve as an Example for EC Consumer Law?", German Law Journal, Cilt 12, Sayı 7, Y1l 2006, s. 1116. ÖZLÜK, s. 91.

39 Bu yönde bkz. ÖZLÜK, s. 91, 92; BAŞ SÜZEL, s. 341, 350; DÖNMEZ, s. 363. 
sonuçları ile ilgili son bir defa uyarılması, tüketicinin korunması amac1na etkin bir şekilde hizmet edebilecek bir araçtır. Bununla birlikte, uygulamada internet satışlarında bu bilgi verme yükümlülüğü, siparişin oluşturulmasındaki son aşamada, ödeme onayından evvel, internet sayfasinda ürünün ve kargolama ücretinin gösterilmesi ve kurulacak mesafeli satım sözleşmesi ile ön bilgilendirme metnini "Okudum, anladım." sekmeleri ile sağlanmaktadır. Kanımızca, tüketicinin şartları tek tek okumaksızın bir "global kabul" eğiliminde olduğu kabul edildiğinde, bu yöntemin ne kadar işlevsel olduğu tartışmaya açık hale gelir.

Tüketicinin cayma hakkına ilişkin bilgilendirilmemesinin yaptır1m1, Yönetmelik md. 10/2'de düzenlenmiştir. Buna göre, eğer tüketici cayma hakkına ilişkin gerektiği şekilde bilgilendirilmezse, bu hakkı bir yıl içerisinde yapılan bilgilendirmenin ardından on dört gün içinde kullanılabilir. Tüketicinin cayma hakkına ilişkin olarak bilgilendirilmesi yükümlülüğü sadece cayma hakkının "varlığına" ilişkin değildir, ayrıca cayma hakkının kullanılacağı süre, taşıyıcının bilgileri gibi unsurları da içerir. Bunun yanında somut olayda cayma hakkının mevcut olmadığı istisnai hallere ilişkin bilgilendirmenin yapılmaması halinde, tüketicinin cayma hakkını kullanabilir hale geleceği kabul edilmektedir ${ }^{40}$. Diğger bir deyişle, tüketici istisnai hali bilmeksizin sözleşme yapmış ise, bu istisna ona karşı ileri sürülemez, tüketici cayma hakkını kullanabilir. Ayrıca tüketici cayma hakkı konusunda bilgilendirilmemişse, bu süre içerisinde yaptığı kullanımın mutat kullanım çerçevesinde kalması beklenmez ${ }^{41}$. Diğer bir ifade ile, tüketici cayma hakkına ilişkin bilgilendirilmeksizin malı gerçek anlamıyla kullanmış ve mutat kullanımı aşmış ise, malda meydana gelen değişimlerden sorumlu olmaksızın cayma hakkını kullanabilecektir. Esasında bu husus, Direktif md. 14/2 de açıça düzenlenmiştir ${ }^{42}$. Türk Hukukunda benzer bir düzenleme olmasa da kanımızca aynı yorumu yapma gerekir ${ }^{43}$. Zira cayma hakkının var olduğunu bilmeyen veya bu hakkı usulüne uygun kullanmak için gerekli bilgileri

$40 \quad$ BAŞ SÜZEL, s. 362; MODUL 2, s. 11; GUIDANCE, s. 37.

41 Esasında tüketici, aşağıda da incelendiği üzere, kural olarak mutat kullanımı aşan fiillerin yarattığı değişim ve bozulmalardan sorumludur. Bkz. TKHK md. 48/4, Yönetmelik md. 13/2.

42 "...The consumer shall in any event not be liable for diminished value of the goods where the trader has failed to provide notice of the right of withdrawal in accordance with point (h) of Article 6(1)."

43 Aynı yönde görüş için bkz. BAŞ SÜZEL, s. 363; YÜCEDAĞ GÖZTEPE, s. 680. 
elde edemeyen tüketicinin, malı bu süre içerisinde kullanmamasının beklenmesi, hayatın olağan akışı ve dürüstlük kuralı ile bağdaşan bir sonuç değildir.

Tüketici cayma hakkını kullandığı vakit, Yönetmelik md. 12/3 gereği, malı satıcının ön bilgilendirmede belirttiği taşıyıcı aracılığıyla geri göndermesi halinde, iadeye ilişkin masraflardan sorumlu tutulmamaktadır. Satıcı ön bilgilendirmede iade için herhangi bir taşıyıcıyı belirtmemiş ise, yine tüketiciden iade masrafına ilişkin bedel talep edilemez. Eğer belirtilen taşıyıcı, tüketicinin bulunduğu yerde şube sahibi değilse, satıcı hiçbir bedel talep etmeksizin malı tüketiciden almakla yükümlüdürr4. Uygulamada taşıyıcı bilgileri genellikle, satışa aracılık eden etkileşimli internet sitelerinin "iade koşulları" başlıklı bilgilendirme notlarında yer almaktadır. Uygulamada tartışmalı olabilecek bir husus, belirtilen taşıyıcının tüketicinin bulunduğu yerde bir şubesinin bulunmaması halidir. Hükümdeki "bulunduğu yer" ifadesi, kanımızca yerleşim yeri olarak değerlendirilmelidir. Uygulamada bu amaçla kullanılan kargo firmalarının pek çok küçük ilçe merkezinde ve köyde şubesi bulunmadığı düşünüldüğünde, satıcının bu hükmün gereğini yerine getirmede "istekli" olmaması durumunun yaratacağı sonuç, düşündürücüdür.

\section{c. Cayma Hakkının Kullanılmasında Şekil ve Süre}

Tüketicinin cayma hakkını kullanabilmesi için, Yönetmelik md. 11/2 gereği Yönetmelik ekinde yer alan formları kullanması yeterlidir. Fakat bu yöntem zorunluluk arz etmez. Tüketici bu anlama gelecek bir beyan ile cayma hakkını kullanabilir ${ }^{45}$. Cayma hakkının kullanıldığının ispat yükümlülüğü ise, Yönetmelik md. 11/4 gereği tüketiciye aittir ${ }^{46}$. Uygulamada internet satışlarında bu beyan genellikle, satışa aracılık eden internet sitesinde kurulmuş bir sistem ile sağlanmakta ve tüketici "iptal/iade" butonu ile cayma hakkını kullandığını beyan etmektedir.

44 Yönetmelik md. 12/3 hükmü, satıcının iade masraflarından sorumlu olmadığını düzenleyen Direktif md. 14 hükmünden ayrılmakta ve tüketiciyi daha fazla korumaktadır. Bu durum öğretide isabetli olarak eleştirilmiş, tüketiciye tanınan bu keyfi şekilde sözleşmeyi sona erdirme imkanının satıcıyı parasal yükümlülük altına sokmaması gerektiği belirtilmiştir. Bkz. ÇABRİ, s. 888 .

45 DÖNMEZ, s. 371; STEENNOT, s. 110; GUIDANCE, s. 40; AVCI BRAUN, s. 38.

46 Tüketici cayma hakkını telefon görüşmesi aracılığıyla kullanıyor ise, bunu ispatla yükümlüdür. Zira, telefon kayıtlarından görüşmenin içeriğini tespit etmek mümkün değildir. Bkz. Yarg. 13. HD, E. 2012/11225, K. 2012/14730, T. 5.6.2012 (Kazanc1 İçtihat Bilgi Bankası- Erişim Tarihi 09.07.2021). 
Yönetmelik md. 9/1 gereği, tüketici “on dört gün içinde herhangi bir gerekçe göstermeksizin ve cezai şart ödemeksizin sözleşmeden cayma hakkına sahiptir." Cayma hakkının kullanan tüketici on gün içinde söz konusu malı satıcıya göndermekle (Yönetmelik md. 13/1), satıcı ise on dört gün içinde ödediği bedeli tüketiciye iade etmekle yükümlüdür (Yönetmelik md. 12/1). Bu doğrultuda satıcı, tüketiciye yapacağı iadeyi tüketicinin kullandığı ödeme aracına uygun biçimde yapmalıdır (Yönetmelik md. 12/2). Ayrıca bedelin tüketiciye iadesi için yapılan masraflara da satıcı katlanmaktadır. Örneğin bedelin kredi kartına iadesi için yapılacak havale masrafı satıcıya ait olacaktır ${ }^{47}$. Internet satışları, hemen her zaman kredi kartı veya havale aracılığıyla yapılan işlemler olduğu için, ücret iadesi de bu araçlarla gerçekleştirilmektedir. Dolayısıyla satıcının bedel iadesini aynı internet sitesinde kullanılacak bir hediye çeki veya para yerine geçen puan gibi yöntemleri kullanarak yapacağına dair tek taraflı beyanları sonuç doğurmaz ${ }^{48}$. Elbette, satıcı ve tüketici iade aracı konusunda farklı bir kararlaştırma yapabilirler. Fakat bu aşamada şuna dikkat çekmek gerekir: Satıcının, iadenin farklı bir yöntem ile gerçekleştirileceğine yönelik önceden mesafeli satım sözleşmesine ekleyerek tüketiciye sunduğu ve müzakere olanağı olmayan kayıtlar, kanımızca haksız şart niteliğinde sayılabilir. Zira para iadesini elde edemeyen ve örneğin yine hediye çeki ile alışverişe zorlanan tüketicinin ekonomik menfaatinin ihlal edildiği açıtır. Bu durum TKHK md. 5/2 gereği söz konusu kaydın hükümsüz olmasına neden olacaktır ${ }^{49}$.

Tüketici, kendisine teslim edilen ürünün ayıplı olması halinde dilerse ayıp hükümlerine başvurabilir, dilerse cayma hakkını kullanabilir. Fakat bu ihtimalde de cayma hakkını kullanma süresinin on dört gün ile

47 ÇABRİ, s. 888.

48 GUIDANCE, s. 46.

49 Haksız şart, tüketici ile müzakere edilmeden sözleşmeye eklenen ve sözleşmeden doğan hak ve yükümlülük dengesini dürüstlük kuralına aykırı şekilde tüketici aleyhine değiştiren kayıtlardır. Buradan tüketicinin haksız şartlar ile ilgili önceden bilgilendirilmesi yeterli değildir. Gerçek anlamıla bir müzakere imkânı aranır. Bkz. AKIPEK ÖCAL, Şebnem, "Hukukumuzda Haksız Şartlar ve Sonuçları", Yeditepe Üniversitesi Hukuk Fakültesi Dergisi Tüketici Hukuku Sempozyumu Özel Sayı, Cilt XII, Sayı 2, Yıl 2015, s. 207, 208. Kanımızca iade yönteminin değiştirilmesi ve tüketicinin bir hediye çeki yöntemi ile aynı internet satıcısından alışverişe zorlanması da -somut olayın şartları dahilinde- tüketici bakımından haksız şart olarak değerlendirilebilir. 
sınırlı olduğu dikkatten kaçmamalıdır. Fakat sözleşmede kararlaştırılan şeyden başka bir şeyin ifası (ailud ifa) söz konusu ise, sözleşmede kararlaştırılan şeyden başka bir şeyin teslimi söz konusu olduğu için, borç ifa edilmemiş sayılacağından, cayma hakkının kullanılması söz konusu olmaz. Bu durumda tüketicinin malın iadesi için on dört günlük süre ile bağlı olmayacağın kabul etmek gerekir ${ }^{50}$. Örneğin uygulamada sık görülen bir sorun olan; tüketiciye 1smarladığ1 yüksek fiyatlı elektronik ürünler yerine basit ve ucuz nesnelerin yollanması örneklerinde, kanımızca aynı esas geçerli olacak ve tüketici on dört günlük cayma süresi ile sinirlı olmayacaktır.

\section{MUTAT KULLANIM KAVRAMI}

\section{A. Mutat Kullanım Kavramının Sınırları}

TKHK md. 48/4 ve Yönetmelik md. 13/2 gereği, cayma hakkını kullanan tüketici sadece malın "mutat kullanımı" dışında kalan fiillerin yarattığ1 değişim ve bozulmalardan sorumludur. Direktif md. 14/2'ye göre de tüketici yalnızca malın yapısını, niteliğini ve kullanımını kavramak için gerekli olan fiiller dışında kalan kullanımdan kaynaklanan değer azalmalarından sorumlu olur. Tüketici, mutat kullanım kavramı çerçevesinde kalan fiillerin sonuçlarından ise sorumlu olmayacak, bundan kaynaklanan değer azalmalarını tazmin etmek zorunda olmayacaktır$^{51}$. Esasında bu, cayma hakkının doğasına uygun bir kabuldür. Zira tüketici, mesafeli bir sözleşme ile satın aldığı malı kontrol etmek amacıyla olağan şekilde muayene edebilecek kadar dahi kullanma hakkına sahip olmasaydı, cayma hakkı işlevini yitirirdi ${ }^{52}$. Bunun yanında, tüketicinin mutat kullanımın aşılmasından kaynaklanan tazmin sorumluluğunun doğması için, bu konuda bilgilendirilmiş olması gerekir. Dolayısıyla tüketici, mutat kullanımı aşması halinde bundan kaynaklanacak tazmin sorumluluğuna ilişkin bilgilendirilmemişse, bu yükümlülük doğmaz ${ }^{53}$. Bu nedenle tüketicinin cayma hakkına ilişkin bilgilendirilmesi yükümlülüğünün mutat kullanım ve onun aşımı sonucunu da kapsar şekilde değerlendirilmesi gerekir.

\footnotetext{
50 DÖNMEZ, s. 371.

51 AVCI BRAUN, s. 38; BOZBEL/ATALI, s. 473.

52 ABRIL/BLANQUEZ/EVORA, s. 41; BOZBEL/ATALI, s. 473.

53 Bu yönde bkz. DÖNMEZ, s. 375.
} 
Sonuçları itibarıyla tüketiciyi ciddi bir ekonomik yük altına sokabilecek olan mutat kullanım kavramının kapsamını doğru biçimde tespit etmek gerekir. Öğretide mutat kullanım kavramı, genel olarak dar biçimde yorumlanmaktadır. İlk olarak Direktif'in yorumunda, tüketicinin mutat kullanımının, esasında tüketici fiziken malın satıldığı ortamda, yani örneğin dükkânda olsaydı, malı nasıl inceleyecek ve deneyecek idiyse, o şekilde kullanması olduğu işaret edilmiştir. İşte bunu aşan davranışlar, mutat kullanımın aşılması anlamına gelir ${ }^{54}$. Bu esas, Direktif'in gerekçesinin 47. paragrafında açıkça ifade edilmiştir ${ }^{55}$. Mutat kullanım kavraminin bu kapsamda yorumlanması, esasında kanun koyucunun mesafeli satım sözleşmesi yapan tüketiciyi menfaat dengesi bakımından mağazadan alışveriş yapan tüketici ile aynı konuma getirmek istemesinden kaynaklanır. Keza, mağazadan alışveriş yapan tüketici de bu esnada malı dilediği gibi denemek ve kullanmak imkanına sahip olmayacaktır ${ }^{56}$. Mutat kullanım kavramı Türk Hukukunda da çoğunlukla benzer bir biçimde dar yorumlanmaktadır. Buna göre, tüketicinin malı oldukça geniş şekilde kullanması fakat yine de sözleşmeden hiçbir değer kaybını tazmin etmeden cayması mümkün olursa, bu satıc1-tüketici arasındaki menfaat dengesini hakkaniyete aykırı biçimde bozar ${ }^{57}$. Keza, mesafeli satım sözleşmesi, muayene şartıyla satım anlamına da gelmez ${ }^{58}$. Örneğin, bir mağazadan bilgisayar satın almak isteyen kişi, bilgisayara yazılım yükleyemez. Dolayısıyla bir internet sitesinden satın aldığı bil-

STEENNOT, s. 111; MODUL 2, s. 14.

55 "In order to establish the nature, characteristics and functioning of the goods, the consumer should only handle and inspect them in the same manner as he would be allowed to do in a shop. For example, the consumer should only try on a garment and should not be allowed to wear it. Consequently, the consumer should handle and inspect the goods with due care during the withdrawal period."

56 ROTT, s. 1126.

57 Bu yönde dar yorum için bkz. DÖNMEZ, s. 375; YILDIRIM, Abdulkerim, Mesafeli Sözleşmelerde Tüketicinin Korunması, İstanbul 2010, s. 258; İNAL, Emrehan, “Mesafeli Sözleşmelerde Tüketicinin Korunması ve Buna İlişkin Güncel Gelişmeler", Uluslararası Tüketici Hukuku Sempozyumu Metinler Kitabı, İstanbul Kültür Üniversitesi Yayınları No: 189, İstanbul 2013, s. 130; BOZBEL/ATALI, s. 472, 473; YÜCEDAĞ GÖZTEPE, s. 679.

58 BAŞ SÜZEL, Ece, “Mesafeli Sözleşmelerde Tüketicinin Sözleşmenin Kurulmasından Sonra Korunması: Cayma Hakkı", Bahçeşehir Üniversitesi Hukuk Fakültesi Dergisi, Cilt 13, Sayı 169-170, Yıl 2018, s. 257 vd. Karş. Bozbel'e göre, burada muayene şartı ile satımın bir türü söz konusudur. Bkz. BOZBEL, s. 799. 
gisayara yazılım yüklerse, bundan kaynaklanan değer azalmasını tazmin etmek zorundadır ${ }^{59}$. Bir mağazadan ses veya görüntü kaydeden bir cihaz almak isteyen kişi, bu cihaza ses/görüntü kaydetmeyi deneyebilir ${ }^{60}$. Elektrikli mutfak aletleri satın almak isteyen kişi, bu ürünlerin mekanik aksamını test etmek dışında, gerçek anlamıyla malzeme ile birlikte deneyemez. Zira bu türden bir deneme sonrası üründe eski hale getirilemez ${ }^{61}$. Telefon alacak olan kişi, sim kartın bu telefona takıp kullanamaz $^{62}$. Fakat uygulamada, bu dar yorumu aşan kararlara da rastlanmaktadır. Örneğin Alman Federal Mahkemesi elektronik ürünlere ilişkin olmasa da bir kararında, su yatağı alan tüketicinin, ürünü evine götürüp içine su doldurarak denedikten sonra sözleşmeden caymasında mutat kullanımın aşılmadığına, su yatağının ancak bu şekilde denenebileceğine ve tüketicinin denemeden kaynaklanan değer azalmasını tazmin etmek zorunda olmadığına hükmederek mutat kullanım kavramını geniş yorumlamıştır ${ }^{63}$. Bu noktada ayrıca şunu da önemle vurgulamak gerekir: Mutat kullanımın aşılması bahsinde ölçüt, bizatihi malın tüketicinin elinde kaldığı süre olmamalıdır. Zira cayma hakkını kullanmada acele etmesi gerektiğini düşünen tüketici, yine rasyonel olmayan kararlar verebilir. Bu ise cayma hakkının amacı ile bağdaşmaz ${ }^{64}$. Önemli olan, kullanımın niteliği olmalıdır.

Malın ambalajının açılması da mutat kullanım kavramı ile doğrudan ilgili bir husustur. Eğer mal bu türden şeylerin satıldığı mağazalarda ambalajsız bir şekilde sergileniyorsa, malın sadece paketinin açılmış olması mutat kullanımın aşıldığı anlamına gelmez. Bu nedenle açılma sirasında ambalajda meydana gelen tahribat, tazmin edilmesi gereken bir değer azalması değildir ${ }^{65}$. Ayrıca, tüketicinin malın niteliğini anlayabilmek için ambalajından çıkarması gerekiyorsa, bunun da mutat kulla-

59 MODUL 2, s. 14; GUIDANCE, s. 47; LUZAK, s. 9.

60 GUIDANCE, s. 47.

61 GUIDANCE, s. 47.

62 GUIDANCE, s. 47. Ticaret Bakanlığg'nın yayımladığı Güncel Tüketici Uyuşmazlıklarına İlişkin Sıkça Sorulan Sorular' a göre, sim kart takılan telefonun ikinci el haline geldiği kabul edilmektedir. Bkz. s. 49.

63 BGH VIII ZR 337/09 (http://juris.bundesgerichtshof.de/cgibin/rechtsprechung/document.py?Gericht=bgh\&Art=en\&nr=54033).

64 LUZAK, s. 10.

65 ROTT, s. 1128; STEENNOT, s. 111; GUIDANCE, s. 47. Benzer yönde bkz. YÜCEDAĞ GÖZTEPE, s. 679. 
nım kapsamında kaldığı kabul edilmektedir. Fakat tüketicinin ambalajı dürüstlük kuralı çerçevesinde özen yükümlülüğüne uygun davranarak açması gerekir ${ }^{66}$. Bu nedenle malın mutlaka orijinal ambalajı ile iade edilmesi zorunluluğunun, sözleşmede yer alan haksız şartlardan sayılma ihtimali yüksektir ${ }^{67}$. Mal eğer koruyucu film gibi bir ambalaj ile sat1lıyorsa, bunun çıkarılması ancak malın denenmesi için zorunlu ise mümkün olmalıdır ${ }^{68}$. Elbette bu yorum, koruyucu ambalajın tekrar yerine takılamadığ1 ihtimal için geçerlidir. Örneğin telefon ekranlarının koruyucu filmleri, somut olayda çoğu zaman tekrar yapıştırılabilmektedir. Kanımızca bu filmin çıkarılması mutat kullanımın aşıldı̆̆ı anlamına gelmez.

Mutat kullanımın aşılıp aşılmadığı, her somut olayda ayrıca tespit edilmesi gereken bir husustur ${ }^{69}$. Oysa, tüketicinin malı kullanımının sadece deneme aşamasında mı kaldığı, yoksa gerçek bir kullanımın mı başladığı, somut olayda tespiti çoğu zaman imkânsız bir olgudur ${ }^{70}$. Yukarıda da ifade edildiği gibi, bu kavramı geniş yorumlayan yargı kararlarına da rastlanmaktadır. Bu husus tartışılırken, tüketici hukukunun amacını ve bunun ekonomik yapıyla ilişkisini düzenleyen hukuk politikasını bir bütün olarak ele almak gerekir. Kanımızca tüketici hukukunun amacına hizmet edecek olan, bu kavramin dar yorumlanmasıdir. Zira, bu kavramın geniş yorumlanması, aşağıda da ifade edildiği üzere, malda meydana gelebilecek değer azalmasına satıcının katlanacağı anlamına gelir. Kullanım nedeniyle yapısı değişen/zarar gören mal, piyasada ikinci el ürün statüsüne girdiği vakit, satıcının bu nedenle bir gelir kaybı yaşaması muhtemeldir. Zira, tüketici davranışı, ikinci el ürünü kullanılmamış ürün ile aynı değerde görmemek ve aynı bedeli ödememek yönündedir. Bu durumda internet ortamında satış yapan kişilerin, malda meydana gelen değer azalmasına katlanması -elektronik ürünlerin fiyat yüksekliği de düşünüldüğünde-, ekonomik olarak sürdürülebilir bir yöntem midir? Kanımızca bu soruyu olumsuz yanıtlamak gerekir. Zira tüketici hukukunun nihai amacı, toplumun yararını gözetmektir.

\footnotetext{
66 LOOS, Marco, "Rights of Withdrawal", Centre for the Study of European Contract Law Working Paper Series, No. 2009/04, s. 25.

67 YÜCEDAĞ GÖZTEPE, s. 679.

68 GUIDANCE, s. 47.

69 GUIDANCE, s. 47.

70 ROTT, s. 1128.
} 
Bu nedenle hukuk tüketiciyi, ekonominin taşıyabileceği yük oranında koruyabilir. Dolayısıyla bu koruma, pazardaki aktörlerin ekonomik varlığını sarsacak seviyeye gelirse, kendi işlevi ile çelişiri ${ }^{71}$. İnternet satışlarından kaynaklanan değer azalmalarının ekonomik yükünü taşıyamayan satıcının yeniden klasik mağaza satımına yönelmesi durumunda ortaya çıkacak maliyet artışına katlanacak olan ise, yine tüketiciler olacaktır. Görüldügü üzere, ekonomik dengeyi bozan bir düzen, nihai olarak tüketicinin menfaatine hizmet edemez. Ayrıca, internet satışı ile elektronik ürün satın alan tüketici, çoğu zaman ürünün özelliklerini araştırarak hareket etmekte ve esasında bu özelliklere ilişkin araştırma faaliyetini satımdan önce yerine getirmektedir. Bu durumda, ürünün tesliminin ardından yaptığı ise malı fiziksel olarak incelemek ve açarak çalışmasını kontrol etmektir. Bu aşama, zaten mutat kullanım kavramının içerisinde kalmakta ve tüketici malı mağazadan alan kişi ile aynı konuma gelerek mesafeli satımın olası olumsuzlukları giderilmektedir. Fakat mutat kullanımın, tüketicinin malın niteliklerini sadece bir süre gerçek anlamıyla kullanarak anlayabileceği biçiminde geniş yorumlanması, diğer bir deyişle, tüketicinin ürünü bir süre gerçek anlamıyla kullanarak sonrasında iade etmesi, mesafeli satımın adeta ödünç almaya dönüşmesi anlamına gelir. Üstelik, Direktif'in aksine, iade masraflarına da satıcı katlanmaktadır. Biz, bu yorumun nihai olarak tüketici hukukunun işlevi ile bağdaşmadığı kanaatindeyiz.

Tabii, bu tartışma daha ziyade internet/yazılım kullanarak çalışan bilgisayar ve telefon gibi ürünler bakımından söz konusu olmaktadır. Zira bu türden ürünlerde çoğunlukla önceki kullanıcıların izi takip edilebilmekte, ürünü yeniden satın alan kişi de bunu tespit edebilmekte, böylece ürün kaçınılmaz olarak ikinci el haline dönüşmektedir ${ }^{72}$. Böyle olmayan elektronik ürünlerde, somut olayda tüketici malı gerçek anlamıyla kullanmış olsa bile, bunun tespit edilememesi mümkündür. Örneğin, bir ütü satın alan kişinin bunu on dört gün boyunca gerçek anlamiyla kullanması ve son anda cayma hakkını kullanması söz konusu olabilir. Elbette tespit edilemeyen bu durum nedeniyle tüketiciye tazmi-

$71 \quad$ Bu yönde bkz. SİRMEN, s. 2467.

72 Plazma televizyonlardaki akıllı yazılımların daha önce kaç saat izlendiğini tespit edebilmesi, bilgisayarların daha önce yüklenen yazılımların yüklenme tarihlerini tespit edebilmesi, cep telefonlarından IMEI kayıtları nedeniyle yaşanan güvenlik sorunları gibi. 
nat sorumluluğu yüklenmesi söz konusu olamaz. Bu durumda mutat kullanımın aşılmasının tespit edilememesi, bu kullanımın üründe kalıcı bir değer azalması/değişim yaratmadığı anlamına da gelir. Kanımızca bu durumda malı yeniden kullanılmamış olarak satabilecek olan satıcı zaten bir gelir kaybı yaşamayacağı için, bir sorun doğmaz.

\section{B. Mutat Kullanımın Aşılmasının Hukuki Sonucu}

Mutat kullanım kavramını tanımladıktan sonra, şunu tespit etmek gerekir: Mutat kullanımın aşılması tüketicinin cayma hakkını ortadan kaldırır mı? Mutat kullanım kavramını düzenleyen hükümlerin yorumunda öğretinin görüşü, isabetli olarak malın tüketici tarafından mutat kullanımı aşan şekilde kullanılmasının cayma hakkına başvurulmasına engel teşkil etmediği, fakat tüketicinin değer azalmasından sorumlu tutulacağı yönündedir ${ }^{73}$. Keza, Direktif'in gerekçesinin 47. paragrafı aynı esası açıkça düzenlemektedir ${ }^{74}$. Kanımızca Türk Hukuku bakımından da ayn yorumu yapmak gerekir. Zira TKHK md. 48/4 ve Yönetmelik md. 13/2 hükümleri tüketiciyi koruma amacı çerçevesinde yorumlandığında, hükümlerin lafızlarının zıt anlamından, tüketicinin cayma hakkını kullanabileceği fakat malın mutat kullanımı aşmaktan doğan sonuçlardan sorumlu olduğu çıkarılmaktadır. Dolayısıyla hükümler, mutat kullanımı aşan durumları cayma hakkının kapsamı dışında bırakmamaktadır. Üs-

73 MODUL 2, s. 14; GUIDANCE, s. 46; YÜCEDAĞ GÖZTEPE, s. 680. AYDOĞDU’ya göre ise, tüketici malı hor kullanmış ise, bu tüketicinin malı beğendiği ve cayma hakkını kullanmayacağı anlamına geldiğinden, artık cayma hakkı kullanılamaz. Bkz. AYDOĞDU, Kılavuz, s. 138. Yargıtay da bir kararında, sözleşmeyi benimsemeye yönelik davranışların ardından cayma hakkının kullanılmasını, dürüstlük kuralına aykırı bulmuştur: "Sözleşmenin yapıldığı tarihten fesih tarihine kadar uzun zaman geçmiş ve davacı borcun büyük kısmını ödemiş̧ir. Bu durumda sözleşmenin davacı tarafça benimsendiğinin kabulü gerekir. Sözleşmenin bu şekilde benimsenmesinden sonra cayma belgesi verilmediği gerekçesiyle fesih talebinde bulunmak iyi niyet kurallan ile bağdaşmaz." Bkz. Yarg. 13. HD, E. 2004/15679, K. 2005/4033, T. 10.3.2005. Aynı yönde bkz. Yarg. HGK, E. 2017/13-637, K. 2017/757, T. 19.4.2017. Fakat Yargitay'ın aksi yönde karar verdiği ve bilgilendirme yükümlülüğünün yerine getirilmediği her halde cayma hakkının süreye bağlı olmadan kullanılabileceğini ifade ettiği kararları da mevcuttur. Bkz. Yarg. 13. HD, E. 2004/14235, K. 2005/1804, T. 8.2.2005; Yarg. 13. HD, E. 2004/5531, K. 2004/14707, T. 18.10.2004; Yarg. 13. HD, E. 2002/2246, K. 2002/5136, T. 6.5.2002 (Kazancı İçtihat Bilgi Bankas1- Erişim Tarihi 09.07.2021).

74 "Some consumers exercise their right of withdrawal after having used the goods to an extent more than necessary to establish the nature, characteristics and the functioning of the goods. In this case the consumer should not lose the right to withdraw but should be liable for any diminished value of the goods." 
telik tüketici hukuku kuralları tüketiciyi koruma amacı taşıdığından, bu kuralların tüketici lehine yorumlanması gerekir ${ }^{75}$. Bu ilke ve normun koruma amacı birlikte düşünüldügünde, kanımızca aksi bir yorumla cayma hakkına hükümde yer almayan bir sınırlama getirmek isabetli olmayacaktır ${ }^{76}$. Eğer kanun koyucu mutat kullanımı aşan durumları cayma hakkının kapsamı dışında bırakacaksa, bunu açıkça ifade etmelidir.

Mutat kullanımın aşılması cayma hakkını ortadan kaldırmasa da tüketicinin malda meydana gelen değer azalmasını tazmin etmekle yükümlü olması kanımızca oldukça yerinde bir düzenlemedir. Zira tüketicinin malı istediği gibi kullanarak on dört gün sonunda hiçbir tazminat ödemeden iade edebilecek olması, yukarıda da incelendiği üzere, oldukça hakkaniyete aykırı sonuçlar doğururdu ${ }^{77}$. Tüketicinin değer kaybını tazminde izlenecek en pratik yol ise, cayma hakkının kullanan tüketiciye iade edilecek olan ürün bedelinin bu miktarda indirilmesidir ${ }^{78}$. Bu durumda, mutat kullanımın aşıldığı ve malda değer azalması meydana geldiğini ispat yükü ise, satıcının üzerinde olacaktır ${ }^{79}$. Fakat bunun için, tüketicinin mutat kullanımın aşılması durumunda bundan kaynaklanan değer azalmasını tazmin etmekle yükümlü olacağı yönünde önceden bilgilendirilmesi gerekir. Aksi halde değer azalması tüketiciye yüklene-

75 SIRMEN, s. 2472.

76 Benzer yönde bkz. DÖNMEZ, s. 375.

77 Bu yönde bkz. BOZBEL/ATALI, s. 472.

78 Yargıtay bir kararında, cayma hakkına konu olan elektrikli süpürgedeki değer azalması oranı olan \%24'ün tüketici tarafından fiilen ödenen bedel üzerinden değil, tüm satış bedeli üzerinden hesaplanması gerektiğini ifade etmiştir. Fakat Yargitay burada değer azalmasının hesaplanması yöntemine açıkça değinmemektedir: "Hükme esas alınan ek raporda, süpürgenin davacıda kaldı̆̆ı süre içinde uğradığı değer kaybı yüzdesi \%24 olarak bulunmuştur. Ancak bulunan bu değer kaybr yüzdesinin süpürgenin satı̧̧ bedeli olan 2250 dolara yansımasının bulunması gerekirken, davacının ödediği 1270 dolara yansıması bulunmuştur. Mahkemece yapılacak iş, süpürgenin değer kaybı yüzdesinin toplam satış bedeline yansıması bulunmalı, böylece elde edilecek değer kaybı, davacının ödediği 1270 dolardan düşülmeli, geri kalan miktarın davacıya iadesine karar verilmelidir. Mahkemece bu yönler gözetilmeden, yazll şekilde karar verilmesi usul ve kanuna ayklrn olup, bozma nedenidir." Bkz. Yarg. 13. HD, E. 2000/6249, K. 2000/6518, T. 3.7.2000 (Kazanc İçtihat Bilgi Bankası- Erişim Tarihi 09.07.2021).

79 STEENNOT, s. 111; MODUL 2, s. 15; LOOS, s. 25. Avrupa Birliği Adalet Divanı, ulusal hukukların malın mutat kullanımının aşılmadığını ispat yükünü tüketiciye yüklemesinin tüketicinin etkin biçimde korunmasını önüne geçeceği yönünde karar vermiştir. Bkz. CJEU C-489/07 Pia Messner (Para 27). 
$\mathrm{mez}^{80}$. Dolayısıyla bilgilendirme yükümlülüğünün ihlali, mutat kullanımın aşılmasının olası sonuçlarını ortadan kaldırmaktadır.

Tüketicinin sorumluluğunu belirleyebilmek için, mutat kullanımın aşılmasının yarattığı değer azalması ile kastedilenin ne olduğunu tespit etmek gerekir. Malda meydana gelen değer azalması, en basit ifadesiyle malın temizlenmesi ve onarılması için yapılacak masraflar ile eğer mal artık yeni ve kullanılmamış olarak satılamayacak durumda ise satıcının malı kullanılmış (ikinci el) bir mal olarak satmasından kaynaklanan gelir kaybıdır $^{81}$. Bu hesaplanırken, malın objektif piyasa değeri dikkate alınmalıdır ${ }^{82}$. Kullanılmış ürün haline gelen maldaki değer kaybı ise, esasında malın o sürede kullanımı için ödenecek kira parasından çok daha fazla bir miktara denk gelir. Zira bu durumda mal "ikinci el" eşyaya dönüşerek ciddi bir değer kaybı görmektedir ${ }^{83}$. Fakat, tüketiciye yansıtılacak değer kaybı bedeli çok yüksek olursa, tüketicinin malı iade ederek ekonomik olarak elverişsiz duruma düşmesi, adeta cayma hakkının kullanılmasının önünde bir engel teşkil eder ${ }^{84}$. Tüketicinin sorumluluğunda olan değer kaybını satıcının omzuna yüklemek ise piyasa dengesini bozabilecek ve satıcıların mesafeli satım yöntemlerinden çekinmesine neden olabilecek bir rizikodur. İşte bu noktada, piyasada satıcı ve tüketici arasında menfaat dengesinin sağlanabilmesi için, tüketicinin bu konuda bilgilendirilmesi çok önemli bir rol oynar. Tüketici, malı basitçe test etmenin ötesindeki gerçek kullanımlarından kaynaklanacak değer azalmasının ve malın ikinci el halinde dönüşmesinin neden olacağı iade indiriminin farkında olabilirse, davranışlarını buna göre düzenleyebilir ${ }^{85}$. Bu nedenle, satıcının cayma hakkının şartları bakımından tüketiciyi bil-

80 STEENNOT, s. 111; MODUL 2, s. 15; GUIDANCE, s. 48; ABRIL/BLANQUEZ/EVORA, s. 42; DÖNMEZ, s. 375. Yazara göre bu sorumsuzluğun sınırını dürüstlük kuralı oluşturur. Aynı yönde BOZBEL/ATALI, s. 473.

81 GUIDANCE, s. 47.

82 YÜCEDAĞ GÖZTEPE, s. 680.

83 ROTT, s. 1126; STEENNOT, s. 112.

84 ROTT, s. 1126, 1128; STEENNOT, s. 111. Avusturya Yüksek Mahkemesi bir kararında, cayma hakkını kullanarak plazma televizyonu iade eden tüketiciye, 43 saat boyunca kullanıldığı tespit edildiği için ikinci el olarak satılacak olması nedeniyle 2.179 Euro değerindeki bir televizyon için sadece 1.499 Euro iade etmek isteyen bir satıcıyı haksız bulmuş ve değer azalmasını sadece 349 Euro olarak tespit etmiştir. Bkz. OGH, 27.9.2005, Az. 1 Ob 110/05s (Rott, s. 1128)

85 ROTT, s. 1129. 
gilendirme yükümlülüğünün kapsamına, malı mutat kullanımı aşan şekilde kullanması durumunda değer azalmasını tazmin sorumluluğunun doğacağı ve bu sorumluluğun tahmini miktarı bilgisi de girmeli$\operatorname{dir}^{86}$. Aksi halde satıcı tüketicinin söz konusu değer kaybını tazmin etmesini talep edememelidir ${ }^{87}$. Fakat uygulamada, bu bilgilendirme yükümlülüğünün yerine getirilmediği görülmektedir. Tespit edebildiğimiz kadarıyla, piyasada yüksek pazar payına sahip internet satıcıları standart bilgi notlarında cayma hakkının varlığına ve mutat kullanımın aşılması halinde değer kaybından sorumluluğa yönelik bilgilere yer verse de bu sorumluluğun tahmini sınırları çizilmemektedir. Keza, bu bilgilendirmenin standart metinlerde yer alan ve tüketicinin çoğu zaman okumadığı hükümlerle sağlanması da mümkün görünmemektedir ${ }^{88}$.

Yukarıda yaptığımız açıklamalar doğrultusunda, kanımızca internet sitesinden satın aldığ 1 cep telefonuna sim kart takan veya bilgisayarına yazılım yükleyen kişi mutat kullanımı aşmış sayılır, fakat bu durum, cayma hakkını kaybettiği anlamına gelmez. Fakat uygulamada internet satışı yapan pek çok elektronik ürün satıcısı sıkça sorulan sorular veya iade/değişim bilgilendirme sekmelerinde, tüketiciye sağlanan cayma hakkını kısıtlar nitelikte notlar barındırmakta, örneğin sim kart takılan cep telefonunun, kablosuz internete bağlanan bilgisayarın veya yazılım yüklenen bilgisayarın cayma hakkı kapsamında iade edilemeyeceği yönünde ifadelere yer vermektedir ${ }^{89}$. Bazı satıcılar ise bu türden şartları mesafeli satım sözleşmesine ekleyerek tüketiciye dayatmaktadır. $\mathrm{Bu}$ durumun uygulamada sıkça görülmesi, elektronik sözleşmelerin katılmalı (iltihaki) sözleşmeler olmasından kaynaklanır ${ }^{90}$. Katılmalı sözleşmelerde, sözleşme taraflarından biri, diğer tarafın önceden hazırladığ1 sözleşme şartlarına müzakere olanağı olmaksızın katılmakta ve sözleşme kurulmaktadır. Bu nedenle katılmalı sözleşmelerin içeriği genel işlem şartlarından oluşmaktadır ${ }^{91}$. Dolayısıyla internet yoluyla sözleşme

\footnotetext{
86 ROTT, s. 1126.

87 ROTT, s. 1128.

88 Bu sorun, sadece Türk Hukuku bakımından değil, Avrupa Birliği mevzuatını ulusal yasalara entegre eden üye devletler bakımından da mevcuttur. Üye ülke uygulamalarında bu sorun için bkz. ROTT, s. 1128.

89 BOZBEL/ATALI, s. 457, 458.

90 AKKURT, s. 33; UYUMAZ, s. 915.

91 AKKURT, s. 33; UYUMAZ, s. 915.
} 
kurmak isteyen tüketici ya satıcının sunduğu şartları kabul eder, ya da sözleşme kurulmaz ${ }^{92}$. Tüketici sözleşmeyi kurmak istiyorsa, kabul tuşuna basılması ile kabul beyanında bulunmuş sayılır ${ }^{93}$. Elektronik sözleşmelerin bu niteliği, satıcı/sağlayıcının bazı sözleşme şartlarını tüketiciye dayatma ihtimalini ortaya çıkarır. Fakat tüketiciyi koruyan kurallarının emrediciliği gereği, bunların aksinin kararlaştırılması mümkün değildir. Bu nedenle tüketiciye tanınan cayma haklarının sözleşme ile kaldırılmas1 veya süresinin kısaltılması geçerli sayılmaz ${ }^{94}$. Mesafeli sözleşmelerde tüketiciye tanınan cayma hakkı da aksi kararlaştırılamayan biçimde tanındığından ${ }^{95}$, satıcıların kanunda yer almayan kısıtlamalarla tüketicinin cayma hakkını sınırlaması hukuken geçerli değildir. Tüketici yine de cayma hakkını kullanabilmelidir.

\section{ELEKTRONİK ÜRÜNLER BAKIMINDAN CAYMA HAKKININ İSTISSNALARI}

Yönetmelik md. 15, aksi kararlaştırılmadıkça cayma hakkının kullanılamayacağı bazı istisnai halleri düzenlemiştir. Hükmün özellikle b, e ve $\breve{g}$ bentlerinde yer alan hususlar, doğrudan veya dolaylı olarak elektronik ürünlere ilişkin olduğu için incelenmelidir.

Öncelikle, Yönetmelik md. 15/1/b bendine göre "tüketicinin istekleri veya kişisel ihtiyaçları doğrultusunda hazırlanan mallara ilişkin sözleşmeler"de cayma hakkı kullanılamaz. Örneğin; seri üretimde olmamasına rağmen alıcının isteği üzerinde bazı kişiselleştirilmiş parçalar ve özellikler eklenen bilgisayarlarda cayma hakkı kullanılamaz ${ }^{96}$. Bu istisna, tüketicinin özel talebine göre hazırlanan ürünün bir başkasına satılmasında zorluk olması ve ürünün değerinin düşmesi rizikosundan kaynaklanmaktadır. Fakat tüketicinin isteği üzerine elektronik parçalar ve aksamlar bir araya getirilerek oluşturulan bir bilgisayarda (örneğin ekran, anakart, ekran kartı, klavye gibi unsurların ferden seçilmesi ve satıcı tarafından birleştirilmesi), bu parçaların iadenin ardından tekrar ayrılarak değer azalması olmadan satılması mümkün ise, cayma hakkının kullanılabilmesi gere-

\footnotetext{
92 UYUMAZ, s. 915; DEMIR, s. 68.

93 UYUMAZ, s. 919.

94 SİRMEN, s. 2468; ÇABRİ, s. 882. Bu yönde bkz. AYDOĞDU/KAHVECİ, s. 47. Bu yönde bkz. Yarg. 13. HD, E. 2004/844, K. 2004/8276, T. 31.5.2004 (Kazanci İçtihat Bilgi Bankası- Erişim Tarihi 09.07.2021).

95 YÜCEDAĞ GÖZTEPE, s. 670.

96 GUIDANCE, s. 47.
} 
kir ${ }^{97}$. Alman Federal Mahkemesi de bir kararında, tüketicinin isteği ile hazırlanan bilgisayar seri üretilen parçaların tüketicinin istediği şekilde bir araya getirilmesi ile oluşmuş ise ve bu parçaların makul bir çaba ile değer kaybetmeden sökülmesi ve yeniden satılması mümkün ise, cayma hakkının kullanılabileceğine hükmetmiştir ${ }^{98}$. Görüldüğü üzere, Federal Mahkeme cayma hakkının kullanılabilmesi için bilgisayar parçalarının tüketicinin isteği üzerine üretilmemiş seri üretilen parçaları olmasını aramıştır. Zira seri üretimde olmayan bir parçanın daha sonra aynı değer üzerinden satılamama rizikosu vardır. Bunun yanında parçaları ayırmak için gerekecek işçilik değerinin makul sınırı aşması durumunda, kanımızca değer azalmasının gerçekleştiği varsayılarak bu masrafın tüketiciye yüklenebilmesi gerekir.

Yönetmelik md. 15/1/e ise özellikle yazılım ve bilgisayar sarf malzemelerini düzenlediği için önem taşır. Hükme göre; "malın tesliminden sonra ambalaj, bant, mühür, paket gibi koruyucu unsurları açılmış olması halinde maddi ortamda sunulan kitap, dijital içerik ve bilgisayar sarf malzemelerine ilişkin sözleşmeler"de cayma hakkı kullanılamaz. Örneğin; bilgisayarda izlemek için satın alınan bir DVD’nin koruyucu paketinin açılmaSı, cayma hakkının ortadan kalktığı anlamına gelir ${ }^{99}$. Aynı esas, yazıcı için kartuş almak ve ambalajını açtıktan sonra iade etme talebinde bu-

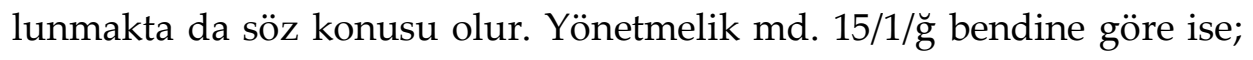
"elektronik ortamda anında ifa edilen hizmetler veya tüketiciye anında teslim edilen gayrimaddi mallara ilişkin sözleşmeler" de cayma hakkı kullanılamaz. Örneğin; cep telefonuna bir uygulama indirildiğinde, indirme işleminin tamamlanması ile uygulama bakımından cayma hakkı kaybedilmiş olur $^{100}$. Aynı doğrultuda, dijital ortamda bir film veya yazılım satın alıp bilgisayara indirdikten sonra bu içerik bakımından cayma hakkı ortadan

\footnotetext{
$97 \quad$ BOZBEL, s. 801.

98 BGH VIII ZR 295/01 (http://juris.bundesgerichtshof.de/cgibin/rechtsprechung/document.py?Gericht=bg h\&Art=en\&Datum=Aktuell\&nr=25935\&linked=urt\&Blank=1\&file=dokument.pdf).

99 BOZBEL/ATALI, s. 464; MODUL 2, s. 10. Tabii, malın ayıplı olması halinde ayıba dayalı giderim hükümlerine başvurma imkânı saklıdır. Örneğin paketi açılan DVD'nin bozuk bir ürün olması halinde, tüketici ayıba dayalı giderim imkanlarına başvurabilecek, örneğin sözleşmeden dönme hakkını kullanırsa bedel iadesi talep edebilecektir.

100 GUIDANCE, s. 54.
} 
kalkar. ${ }^{101}$ Zira işlem tamamlanmış ve ürün kullanılabilir hale gelmiş, hatta bilgisayara veya telefona kopyalanması mümkün olmuştur ${ }^{102}$. Bu durumda, bilgisayar ile birlikte yazılım satın alınması durumunda, eğer yazılım bilgisayara yüklenmiş ise, bilgisayar bakımından cayma hakkı kullanılabilecek, fakat yazılım bakımından kullanılamayacaktır ${ }^{103}$. Bilgisayar ise, daha önce yazılım yüklendiği için kullanılmış bir bilgisayar olarak satılacağından, yukarıda da incelendiği üzere, bu değer kaybının tüketici tarafından tazmin edilmesi gerekir ${ }^{104}$.

Elektronik ürünlerle doğrudan ve dolaylı bir şekilde bağlantılı olan bu türden malzemelerin veya içeriklerin cayma hakkının kapsamı dışında kalması, kanun koyucunun bu unsurları açıça zikretmesi ile mümkün olmaktadır. Fakat yukarıda da ifade ettiğimiz üzere, satıcının cayma hakkının kullanılamayacağı istisnaları genişleten veya cayma hakkının kullanılmasını zorlaştıran bildirimlerinin geçerli kabul edilmemesi ${ }^{105}$ ve tüketicinin cayma hakkını kullanabilmesi, fakat mutat kullanım aşılmış ise üründeki değişikliklerden maddi olarak sorumlu olması gerekir ${ }^{106}$.

Tüketicinin cayma hakkının istisnaları veya cayma hakkını kaybedeceği şartlar konusunda bilgilendirilmesi gerekir. Aksi halde tüketicinin istisna hallerinde dahi cayma hakkını kullanmaya devam edebileceği kabul edilmelidir ${ }^{107}$. Bu esas Yönetmelik md. 15/1/h'de "15 inci madde uyarınca cayma hakkının kullanılamadı̆̆ durumlarda, tüketicinin cayma hakkından faydalanamayacă̆ına ya da hangi koşullarda cayma hakkını kaybedeceğine ilişkin bilgi"nin verilmesi zorunluluğu olarak düzenlenmiştir. Dolayısıyla bu hükümde yer alan bilgi verme yükümlülügüne aykırılık, tüketicinin esasında sahip olmadığı cayma hakkının doğumuna yol açar. Kanımızca bu çıkarım, tüketicinin cayma hakkını kullanamayacağını bilmesi halinde ürünü satın almak konusunda bir kez daha düşüneceği, belki de ürünü bir internet sitesinden satın almaktan vazgeçip mağazada görerek satın almayı tercih edeceği düşünüldügünde, yerindedir.

\footnotetext{
101 UZUN KAZMACI, s. 2809; BOZBEL, s. 800.

102 UZUN KAZMACI, s. 2809; BOZBEL/ATALI, s. 462.

103 Bu yönde bkz. BOZBEL/ATALI, s. 465, 466.

104 Bkz. Yuk. III, B.

105 Modul 2, s. 12.

106 Bkz. Yuk. III, B.

107 DÖNMEZ, s. 375; Modul 2, s. 10
} 
Üstelik bu bilgilendirmenin amacını yerine getirebilmesi için, sadece ön bilgilendirme metninde veya sözleşmenin genel işlem şartlarında yer alması yeterli görülmemelidir. Ürünün üzerinde, tüketicinin açarken göreceği bir uyarının mevcut olması gerekir ${ }^{108}$. Böylece tüketicinin davranışını bu uyarıya uygun olarak şekillendirmesi mümkün olur.

\section{SONUÇ}

Mesafeli sözleşmeler, tüketici satıcıyı ve ürünü görmeden "uzaktan” kurulduğu için, tüketicinin korunması bakımından özellik arz eder. Gerek tüketicinin işlemin şartları hakkında ayrıntılı biçimde bilgilendirilmesi, gerekse cayma hakkının onu sözleşmenin bağlayıcılığından adeta "kurtarması", bu korumanin en önemli göstergeleridir.

Mesafeli satım sözleşmelerinin uygulamadaki en yaygın örneği olan internet satışları ise, piyasadaki işlem yoğunluğu nedeniyle tüketiciye olan etkileri bakımından önem taşır. Diğer ürünlere nazaran daha yüksek fiyatlı olan elektronik ürünlerin daha uygun fiyatlı olması nedeniyle internet siteleri aracılığıla satın alınması, günümüzde tüketiciler arasında çok yaygın bir davranıştır. Bu nedenle internet üzerinden satın alınan elektronik ürünlerde cayma hakkının kullanılması, güncel bir hukuki sorundur.

Cayma hakkı bakımından mutat kullanım kavramı, tüketiciye yüklenecek olası tazminat sorumluluğu nedeniyle, tüketicinin/satıcının menfaat dengesi bakımından dikkatlice tespit edilmesi gereken bir kavramdır. Kanımızca mutat kullanım kavramının dar yorumlanması, nihai olarak tüketicinin menfaatine hizmet eder. Zira tüketici mutat kullanım kapsamında malı mağazadaki kadar inceleyip kullanabiliyorsa, zaten mesafeli satımın yarattı̆ 1 olumsuzluktan kurtulmuş olacaktır. Fakat bunu aşan gerçek kullanım, tüketicinin adeta maldan bir süre bedelsiz olarak faydalanması anlamına gelir. Ayrıca malda meydana gelen değer kaybı, özellikle elektronik ürünlerde satıcıya katlanılması beklenemeyecek bir ekonomik külfet yükler. Bu durum, sonuç olarak piyasa dengesinin bozulmasına, satıcıların geleneksel mağaza satışını tercih etmesine ve nihai olarak fazla maliyetin tüketiciye yüklenmesine neden olur. Aynı esas, değer kaybının belirlenmesi bakımından da geçerlidir. Tüketiciyi koruma düşüncesi ile değer kaybını düşük hesaplamak, maliyeti ise satıcıya yüklemek, aynı gerekçe ile nihai olarak tüketicinin korunamama- 
sına neden olur. Bunun tüketici bakımından çözümü ise, bilgi verme yükümlülügünün gerçek anlamda tüketicinin anlayabileceği ve olası sonuçları somut olarak kavrayabileceği biçimde gerçekleştirilmesidir. Bilgi verme yükümlülüğünün bu şekilde gerçekleştirilemeyeceği ve olası değer kaybının maliyetinin satıcıya yüklenerek bir çözüm bulunması yorumu ise kanımızca isabetli değildir. Bu nedenle, tüketicinin korunması bahsinde her alanda olduğu gibi, cayma hakkı konusunda da bütüncül ve piyasanın tüm aktörlerini koruyan bir yorumda bulunmak ve hukuk politikasını buna uygun olarak şekillendirmek gerekir. Bu nedenle yukarıda da ifade edildiği gibi, malın mutat kullanımının aşılması cayma hakkının kullanılması imkanını ortadan kaldırmamalıdır. Fakat mutat kullanımı aşan tüketici maldaki değişimi/değer azalmasını tazmin etmekle yükümlüdür. Üstelik cayma hakkına ilişkin emredici hükümlerin tüketici aleyhine değiştirilmesi söz konusu olamaz. Aynı esas, cayma hakkının kullanılamayacağı istisnai durumların dar yorumlanması ve taraf iradesi ile genişletilememesi bahsinde de geçerlidir. 


\section{KAYNAKLAR}

AKİPEK ÖCAL, Şebnem, "Hukukumuzda Haksız Şartlar ve Sonuçları", Yeditepe Üniversitesi Hukuk Fakültesi Dergisi Tüketici Hukuku Sempozyumu Özel Sayı, Cilt XII, Sayı 2, Y1l 2015, s. 201-217.

AKKURT, Sinan Sami, "Elektronik Ortamda Hizmet Sunumu ve Buna İlişkin Sözleşmelerin Hukuki Özellikleri”, Ankara Üniversitesi Hukuk Fakültesi Dergisi, Cilt 60, Sayı 1, Y1l 2011, s. 19-46.

AVCI BRAUN, Cihan, "Tüketicinin Korunması Hakkında Kanun Kapsamında Mesafeli Sözleşmeler", Yeditepe Üniversitesi Hukuk Fakültesi Dergisi Tüketici Hukuku Sempozyumu Özel Sayı, Cilt XII, Sayı 2, Y1l 2015, s. 17-45.

AYDOĞDU, Murat, “6502 Sayılı Tüketicinin Korunması Hakkında Kanun'un Getirdiği Yeniliklere Genel Bakış, Sözleşmeye Aykırılık, Ayıplı İfa Kavramlarına Getirdiği Farklı Yaklaşım ve Bu Konudaki Önerilerimiz", Dokuz Eylül Üniversitesi Hukuk Fakültesi Dergisi, Cilt 15, Sayı 2, Y11 2013, s. 1-62.

AYDOĞDU, Murat, Tüketici Kılavuzu-Hukuk Rehberi, On İki Levha Yayınc1lı, İstanbul 2014. (Kılavuz)

AYDOĞDU, Murat/KAHVECİ, Nalan, Tüketici Hukuku, Adalet Yay1nevi, Ankara 2021.

BAŞ SÜZEL, Ece, “Mesafeli Sözleşmelerde Tüketicinin Sözleşmenin Kurulmasından Sonra Korunması: Cayma Hakk1", Bahçeşehir Üniversitesi Hukuk Fakültesi Dergisi, Cilt 13, Sayı 169-170, Y1l 2018, s. 257-307. (Cayma)

BAŞ SÜZEL, Ece, “Mesafeli Sözleşmelerde Tüketicinin Sözleşmenin Kurulmasından Önce Korunması: Ön Bilgilendirme Yükümlülüğü", Galatasaray Üniversitesi Hukuk Fa-kültesi Dergisi, Cilt 2, Say1 2, Y1l 2018, s. 337-370.

BAYSAL, Başak, “Cayma Hakkının Sözleşme Hukukundaki Yeri”, İstanbul Üniversitesi Hukuk Fakültesi Mecmuası, Cilt LXXV, Sayı 1, Yil 2017, s. 273-292.

BOZBEL, Savaş / ATALI, Murat, "Mesafeli Sözleşmelerde Cayma Hakkının Kullanılması ve Ortaya Çıkan Hukuki Sorunlar", Atatürk 
Üniversitesi Erzincan Hukuk Fakültesi Dergisi, Cilt IX, Sayı 1-2, Yil 2005, s. 451-474.

BOZBEL, Savaş, “Türk Hukukunda mesafeli Sözleşmeler”, Atatürk Üniversitesi Erzincan Hukuk Fakültesi Dergisi, Cilt VII, Sayı 3-4, Yil 2003, s. 783-804.

BÜTÜN YILMAZ, Derya G., "Mesafeli Sözleşmelerin Kapsamı”, Ankara Üniversitesi Hukuk Fakültesi Dergisi, Cilt 69, Sayı 2, Y11 2020, s. 325-368.

Consumer Law Module 2, Right of Withdrawal, European Parliment, January 2018, https://www.consumerlawready.eu/sites/default/files/201803/CLR_Module_2_UK.pdf (Çevrimiçi Kaynak).

ÇABRİ, Sezer, Tüketicinin Korunması Hakkında Kanun Şerhi, 2. Baskı, Adalet Yayınevi, Ankara 2021.

DEMIR, Mehmet, “Mesafeli Sözleşmelerle İlgili AB Yönergesine Göre Tüketicinin Geri Alma Hakkı", Gazi Üniversitesi Hukuk Fakültesi Dergisi, Cilt 7, Sayı 1-2, Y11 2003, s. 61- 90.

DG Justice Guidance Document concerning Directive 2011/83/EU of the European Parliament and of the Council of 25 October 2011 on Consumer Rights, Amending Council Di-rective 93/13/EEC and Directive 1999/44/EC, June 2014, https://ec.europa.eu/info/sites/default/files/crd_guidance_en_0. pdf (Çevrimiçi Kaynak).

DÖNMEZ, Zeynep, “2011/83/EU Sayılı Tüketici Hakları Direktifi ve Bu Direktifin Mesafeli Sözleşmeler Alanında Türk Hukuku'na Yansımaları", İnönü Üniversitesi Hukuk Fakültesi Dergisi, Cilt 7, Say1 1, Y1l 2016, s. 351-380.

GEZDER, Ümit, "The Right of Withdrawal in Distance Contracts", Yaşar Üniversitesi E-Dergisi, Say1 8, Y1l 2013, s. 1185-1201.

Güncel Tüketici Uyuşmazlıklarına İlişkin Sıkça Sorulan Sorular, Ticaret Bakanlığı Tüketicinin Korunması ve Piyasa Gözetimi Genel Müdürlüğü, Ankara 2019, (https://ticaret.gov.tr/data/5d43e87b13b876433065530b/e6cc5840 20982965ddb7ff9daa39edd1.pdf) (Çevrimi Kaynak). 
2758 | Dr. Öğr. Üyesi Ayşen ÇíLENTİ KONURALP

İNAL, Emrehan, “Mesafeli Sözleşmelerde Tüketicinin Korunması ve Buna İlişkin Güncel Gelişmeler", Uluslararası Tüketici Hukuku Sempozyumu Metinler Kitabı, İstanbul Kültür Üniversitesi Yayınları No: 189, İstanbul 2013, s.117-131.

KOCAYUSUFPAŞAOĞLU, Necip, Borçlar Hukuku Genel Bölüm, Birinci Cilt, Filiz Kitabevi, 4. Bası, İstanbul 2008.

KURT, Leyla Müjde, “TKHK Açısından Kapıdan Sözleşmelerde Tüketiciyi Koruyan Geri Alma Hakkı", Ankara Barosu Dergisi, Sayı 2, Y1l 2011, s. 43-68.

LOOS, Marco, "Rights of Withdrawal", Centre for the Study of European Contract Law Working Paper Series, No. 2009/04, s. 1-30. (https://papers.ssrn.com/sol3/papers.cfm?abstract_id=1350224).

LUZAK, Joasia, "To Withdraw or Not to Withdraw? Evaluation of the Mandatory Right of Withdrawal in Consumer Distance Selling Contracts Taking into Account Its Behavioural Effects on Consumers", Journal of Consumer Policy, Centre for the Study of European Contract Law Working Paper Series No. 2013/04, s. 138.

(https://papers.ssrn.com/sol3/papers.cfm?abstract_id=2243645).

ÖZLÜK, Betül, “Akıllı Mesafeli Sözleşmelerde Bilgilendirme Yükümlülüğ̈̈", Bilişim Hukuku Dergisi, Sayı 1, Y1l 2020, s. 81-113.

ROTT, Peter, "Harmonising Different Rights of Withdrawal: Can German Law Serve as an Example for EC Consumer Law?", German Law Journal, Cilt 12, Say1 7, Y11 2006, s. 1109-1136.

SÁNCHEZ ABRIL, Patricia / OLIVA BLÁZQUEZ, Francisco / MARTÍNEZ EVORA, Joan, “The Right of Withdrawal in Consumer Contracts: a comparative analysis of American and European Law", InDret, Sayı 3, Y11 2018, s. 1-56.

SİRMEN, A. Lâle, "Tüketici Hukukunun Amacı ve Özellikleri”, Yaşar Üniversitesi E-Dergisi, Say1 8 (Özel Say1), Y1l 2013, s. 2465 2476.

STEENNOT, Reinhard, “The Right Of Withdrawal Under The Consumer Rights Directive As A Tool To Protect Consumers Concluding 
A Distance Contract", Computer Law \& Security Review, Say1 29, Y11 2013, s. 105-119.

UYUMAZ, Alper, “Elektronik Sözleşmelerin Web Siteleri Aracılığıyla Kurulması ve Bu Sözleşmelerin İfası", Dokuz Eylül Üniversitesi Hukuk Fakültesi Dergisi, Cilt 9, Özel Sayı, Y11 2007, s. 907-930.

UZUN KAZMACI, Özge, "İnternet Ortamında Kurulan Mesafeli Sözleşmelerde Tüketicinin Korunması", Marmara Üniversitesi Hukuk Fakültesi Hukuk Araştırmaları Dergisi, Prof. Dr. Cevdet Yavuz'a Armağan Özel Sayısı, Cilt 22, Say1 3, Y1l 2016, s. 27912818.

YILDIRIM, Abdulkerim, Mesafeli Sözleşmelerde Tüketicinin Korunmas1, İstanbul 2010.

YÜCEDAĞ GÖZTEPE, Nafiye, “Mesafeli Sözleşmelerde Tüketicinin Cayma Hakkı", Türkiye Adalet Akademisi Dergisi, Sayı 27, Y1l 2016, s. 667-690. 